\title{
ANTHROPOGENIC INFLUENCES ON SEASONAL CHANGES OF NUTRIENTS, PHYSICAL AND CHEMICAL FACTORS IN THREE COASTAL FRESHWATER SHALLOW LAKES (PORTUGAL)
}

\author{
F. Gonçalves ', R. Ribeiro², V. Vasconcelos 3 , A. M. V. M. Soares. \\ 1 Departamento de Hiologia da Universidade de Aveiro, Campus de Santiago, 3810 Aveiro, Portugal \\ 2 Instituto do Atnbiente e Vida, Departamento de Zoologia da Universidade de Coimbra, ,Largo Marquês de Pombal, 3000 Coimbra, \\ Portugal \\ 3 lnstituto de Zoologia "Dr. Augusto Nobre", Faculdadc de Ciências do Porto, Praça Gomes Teixeira, 4050 Porto, Portugal
}

Key-words: lakes, anthropogenic influence, nutrients, regression models, Portugal

Palabras clave: lagos, influencia antrópica, nutrientes, modelos de regresión, Portugal

\begin{abstract}
Braças, Vela and Mira lakes (near Figueira da Foz - Portugal) are eutrophic bodies of water largely as a result of nutrient loading from the runnof from agricultural areas and suburban watersheds. Despite this situation, Mira lake provides sport fishing/angling and Vela and Braças lakes are, respectively, important environments for community recreation and protection of wildlife. The algal production in the three lakes has varied with nutrient concentrations, primarily phosphorus and nitrogen, and the anthropogenic landuse activities increased the mobilisation of the nutrients in the drainage basin and subsequent loading into the lakes. In Mira lake, the external loading from bait used in sport fishing increases temporally phosphorus and nitrogen into the water body. This finding is the main disturbance within this system. The present study was made to compare the three lakes in order to cxamine seasonal and spatial variations on the environmental parameters and to assess the impact of human activities on physical and chemical structure.
\end{abstract}

\section{INTRODUCTION}

The watcr quality of lake ecosystems is influenced by four main factors: (I) hydrologic fluctuations and hydraulic loading rates; (II) type of vegetation (surrounded forest and macrophytes); (III) type of soil and associated biochemical processes; (IV) anthropogenic influences (e.g. recreational activities, sewage effluents, agricultural activities). Thus, lakes act as sink for nutrients, and the dominant internal biochemical processes in the soil and the water column influence the accumulation of organic matter of planktonic and rnacrophyte origin.

Braças, Vcla and Mira lakes, near Figueira da Foz (Portugal), are important recreational areas and sources of water for agricultural production. Mira and Vela lakes are, respectively, receiving waters of sewage eftluents from small communities and from agricultural areas. Braças lake is an important source of drinking watcr for local urban populations. In the Braças and Vela lakes, water volume depends upon variations in groundwater levels. Mira lake is fed by two ungauged surface streams. During August 1993, Braças lake drained completely. The intensive use of surface waters, manly in Vela and Mira lakes, requires thorough and comprehensive management strategies.

In recent years. aquatic macrophyte growth has become excessive, and the lakes have remained eutrophic, exhibiting dense and severe summer cyanobactcria blooms (BARROS et al., 1993; RODRIGUES et al., 1993; VASCONCELOS, 1994). The basic limnology of these lakes is poorly known, especially with respect to nutrient loading and temporal cycling which condition growth of ecological communities. The effects of these factors on these communities can be expected to vary greatly among the three lakes.

The present study was made to compare the three lakes in order to examine seasonal and spatial variations on the environmental parameters and to assess the impact of human activities on physical and chemical structure. 


\section{MATERIAL AND METHODS}

Physical descriptions of the three lakes arc summarised in Table I. The maximum distance between Braças and Vela is about $5 \mathrm{~km}$ and between Vela and Mira is about $10 \mathrm{~km}$. Braças and Vela lakes are located in a pine forest (western) and surrounded (eastern) by agricultural areas. Mira lake is surrounded by agricultural areas and is located near a small village.

Table 1. Physical characteristics of the Braças, Vela and Mira lakes. Tabla I. Características fisicas de los lagos de Braças, Vela y Mira.

\begin{tabular}{cccc}
\hline & Braças & Vela & Mira \\
\hline Lake area (ha) & 30 & 70 & 40 \\
Lake depth (m) & & & \\
Mean & 0.68 & 1.02 & 2.79 \\
Maximum & 1.10 & 2.10 & 310 \\
Minimum & 0.20 & 0.30 & 2.10 \\
\hline
\end{tabular}

Water samples wcre taken bimonthly, in all lakes, over a period of one year (February 1992 - January 1993). Three sampling stations werc established along each lake and three samples of two litres from the surface water werc taken at each site.

Water parameters analysed include chlorophyll a, dissolved inorganic phosphorus, total phosphorus, dissolved inorganic nitrogen, dissolved oxygen, temperature, conductivity, $\mathrm{pH}$, silicates, ammonium, nitrate, nitrite, $\mathrm{N} / \mathrm{P}$ ratio and alkalinity.

Temperature $\left({ }^{\circ} \mathrm{C}\right.$, accuracy $\pm 0.5^{\circ} \mathrm{C}$ ) and $\mathrm{pH}$ (accuracy \pm 0.02 ) were measured with a $\mathrm{pH}$ meter Jenway 3150 . Conductivity $(\mu \mathrm{S} / \mathrm{cm})$ was measured using a WTW LF92 conductivity meter. Dissolved oxygen $(\mathrm{mg} / \mathrm{l}$, accuracy $<0.1$ $\mathrm{mg} / \mathrm{l}$ ) was measured with a WTW OXI92 oxygen meter.

Ammonium $(\mu \mathrm{g} / \mathrm{l})$ was determined by the KOROLEFF (1970) method. Nitrite $(\mu \mathrm{g} / \mathrm{l})$, nitrate $(\mu \mathrm{g} / \mathrm{l})$, total phosphorus (ygll), dissolved inorganic phosphorus $(\mu \mathrm{g} / \mathrm{l})$, silicates $(\mu \mathrm{g} / \mathrm{l})$ and the alkalinity (ppm CaCO3) were determined according to STRICKLAND \& PARSONS (1972). Chlorophyll a was determined fluorometrically according to STRICKLAND \& PARSONS (1972). The DIN/DIP ratio is calculated when ammonium, nitrite and nitrate values (total inorganic nitrogen) werc added and divided by dissolved inorganic phosphorus (DIP).

\section{Statistical Analyses}

In order to examinate chlorophyll a and dissolved inorganic phosphorus dynamics, the transformed $\left(x^{\prime}=x 1 / 10\right)$ data were used to develop regression models. After having calculated a regression equation for each set of data from all lakes by season, we have compared all slopes () in order to test whether they were equal, utilising an analysis of covariance (Zar, 1984). The null hypothesis (Ho: $\beta a=\beta b=\ldots=\beta k$ ) was rejected and the next step was to employ a multiple comparison test (q slatistic test) to determine which slopes differed from which others (Zar, 1984).

\section{RESULTS}

During the study period (February 1992 - January 1993) the water temperature in the three lakes showed a typical variation for temperate regions: high mean values during summer (Braças: 25.08 \pm 1.35 ; Vela: 24.05 \pm 1.59 ; Mira: 23.35 1.3) and low mean values during winter (Braças: 13.69 2.11 ; Vela: 12.17 \pm 2.79 ; Mira: 11.74 \pm 2.53 ). None of the lakes showed temperature stratification during the study period.

These lakes were characterised by high dissolved oxygen concentrations which have been very constant in Vela (10.3 $\pm 1.59)$ and Braças $(9.13 \pm 1.46)$ lakes, however, in Mira (13.41 +4.22) it showed a peak in February 1992 and January 1993.

The overall trend in water conductivity increased along the time in the considered lakes (from $240 \mathrm{~S} / \mathrm{cm}$ to 780 $\mathrm{S} / \mathrm{cm}$ )

The $\mathrm{pH}$ values were very irregular in Mira lake and varied between 7.5 and 9.5 (Fig. 3). In Vela lakc. the values observed were confined to 8.0-9.0. Braças lake showed smaller values, below 8.2 .

The alkalinity variations were also very irregular along the study period, in the considered lakes. During summer and winter time the Mira values observed wcre higher than Vela alkalinity, but exhibited similar oscillations. In Braças lake, the alkalinity values were higher than Vela values and increased along the period studied until the lake dried. These values ranged from 50 to $140 \mathrm{ppm} \mathrm{CaCO} 3$.

The silicate values during this study period were very regular, constant and low in the Vela lake. The data for Mira lake werc higher and more irregular, with peak values occurring during April and December. These values ranged from 0 to $4 \mathrm{~g} / \mathrm{l}$.

During summer period changes in nitrite concentrations were not observed and the values remained low, in Vela and Mira lakes (Fig. 1). As expected in a natural system nitrite $(<6$ $\mu \mathrm{g} / \mathrm{I})$ was the least abundant form among inorganic $\mathrm{N}$ - 
compounds in three lakes and showed clear seasonal variations. This seasonal pattern was observed for nitrate and ammonium values. The nitrite seasonal variations peaks followed the same temporal pattern as nitrate. In Braqas lake, inorganic $\mathrm{N}$-compounds were very low and remained without variations.

The seasonal changes in total phosphorus in Braqas lake were less marked than Mira (Fig. 2). Marked differences
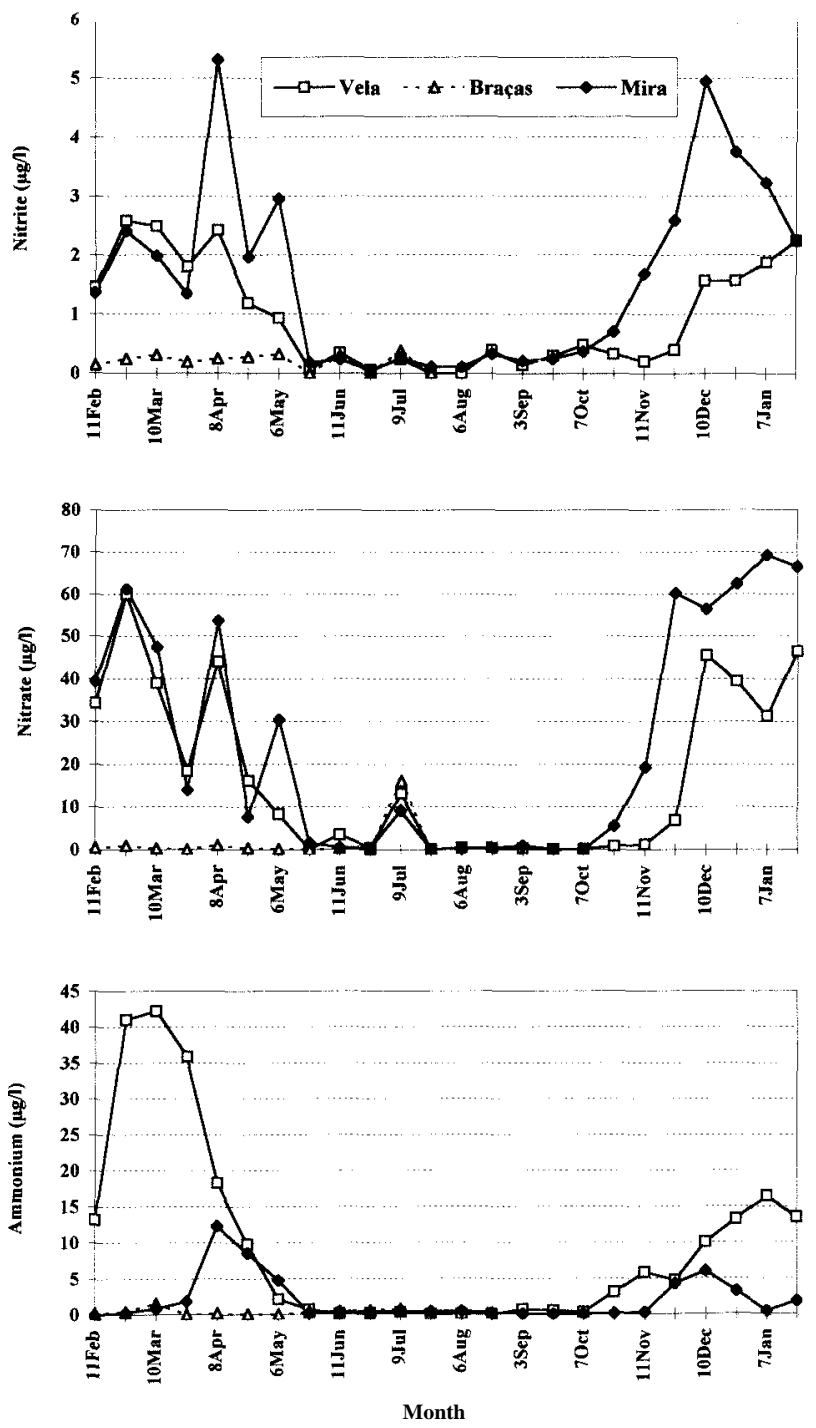

Fig, 1, Anual variation ot mean values for nitrite. nitrate and ammonium in the Braças, Vela and Mira lakes.

Fig. I. Variación anual de los valores medios de nituito, nitrato y amonio en los lagos de Braças. Vela y mira. between Mira and the other two lakes were found during seasonal peaks observed (April, July and December) both in intensity and frequencies.

The chlorophyll a level of Mira lake was always higher than in Braqas or Vela, and showed three peaks: July. November and January (1993). In Braqas, the values observed were very close to those of Vela lake, between February to May. Thereafter, Braças values gradually increased until July. In Vela lake, chlorophyll a concentrations were regular during the study period.

Dissolved inorganic nitrogen (DIN) depends on ammonium, nitrate and nitrite concentrations, the variations along the year being the result of behaviour of those components (Fig. 3). In Braqas lake, DIN was low and very stable. In Vela and Mira lakes, winter and autumn DIN concentrations were higher than late spring and summer values. Dissolved inorganic phosphorus (DIP) concentrations remained stable in Vela lake from February to November-. After this month, the phosphorus concentrations diminished and stabilised until the end of the study period. In Mira lake, observed variations were very strong with maximum values at April and July. After this month, DIP concentrations decreased with oscillations. Those values were always higher than Vela and Braqas lakes. In this lake, the values observed are very similar to those of Vela lake.
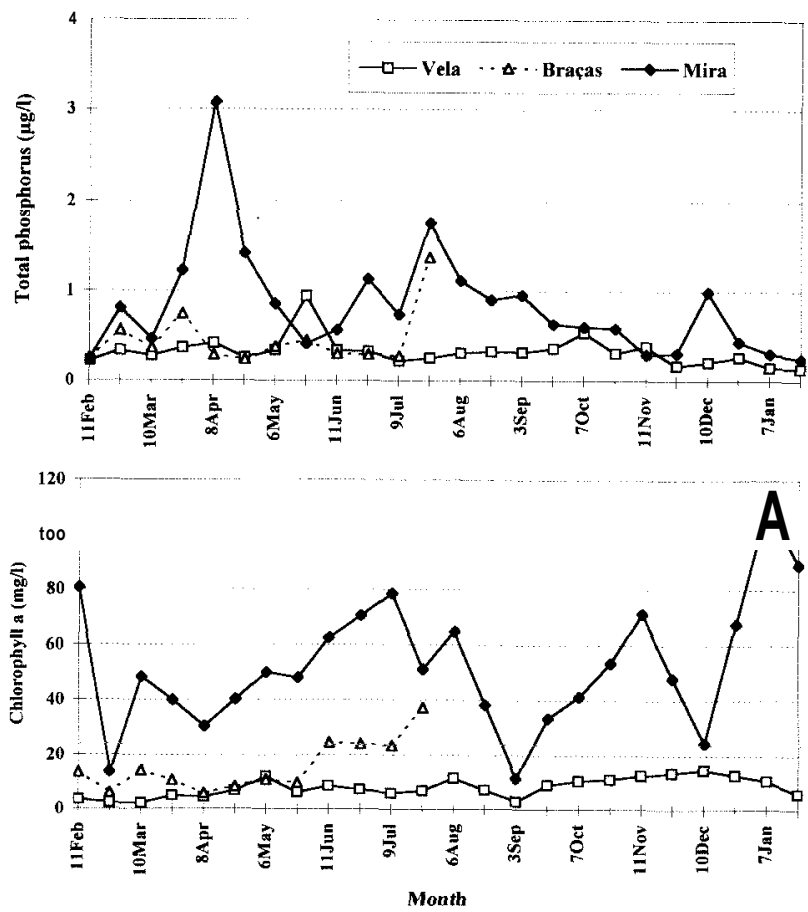

Fig. 2. Anual variation of mean values for total phosphorus and chlorophyll $\underline{\mathbf{a}}$ in the Braças, Vela and Mira Lakes.

Fig. 2. Variación anual de los valores medios de fósforo total y clorofila en los lagos de Braças, Vela y Mira. 
The DIN/DIP ratio was very low between May and early November, in Mira and Vela lakes. Braças lake showed a low and stable DIN/DIP ratio throughout the study period. Higher valucs wcre observed in Vcla lake during February 1992 and Deccmber-January (1993). These ratios were strongly conditioned by the oscillations of DIN values in Vela lake. Low DINIDIP values, in Mira lake, were due to high DIP values associated to a simultaneous DIN decrease from February to May. At the end of the study period the high DINIDIP ratios wcre due to a combined effect of a DIN increase and a DIP decrease.
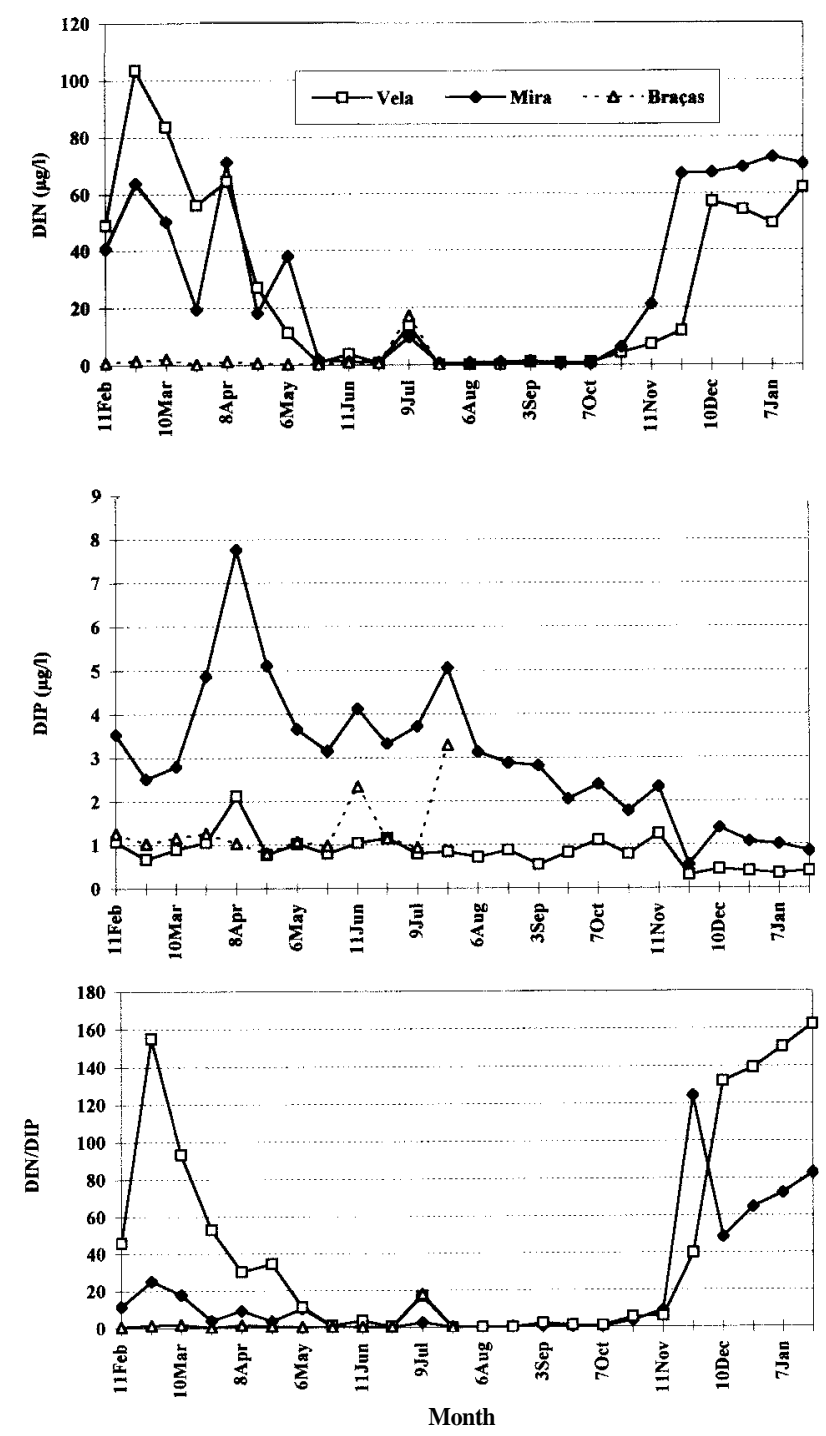

Fig. 7. Annual variation of dissolved inorganic nitrogen (DIN). disolved inorganic phosphorus (DIP) and ratıo DIN/DIP en los lagos de Braças, Vela y Mira.

Fig. 3. Variación anual de nitrógeno inorgánico disuelto (DIN), fósforo inorgánico disuelto (DIP) y razón DIN/DIP en los lagos de Braçcas, Vela y Mira.
I ,! L. 2 Regression models developed for observed chlorophyll a vs DIP values 1 in all lakes.

Tabla 2. Modelos de regresión entre la clorofila a observada y los valores de DIP para los tres lagos.

\begin{tabular}{|c|c|}
\hline Ilinter model & $\begin{array}{c}\text { Chl-a }=0.2875( \pm 0299)+1.0108( \pm 0.2934)[D I P \\
(F-11.87 . \mathrm{P}=0.001, \mathrm{n}=53)\end{array}$ \\
\hline spring model & $\begin{array}{c}(\mathrm{hl}-\underline{a}=04862( \pm 01935)+0.7889( \pm 0.1 \mathrm{X} I) \mathrm{I}) \mathrm{ll}) \\
(\mathrm{l}=18.765 . \mathrm{P}<<0001 . \mathrm{n}=54)\end{array}$ \\
\hline summer model & $\begin{array}{c}(\mathrm{hl}-\underline{a}=-0.1889( \pm 0 \quad 1601)+1.4503( \pm 0) 1525)[) I P \\
(1=90465 . P<<0.001 .11-38)\end{array}$ \\
\hline autumn model & $\begin{array}{l}(\mathrm{hl}-\underline{\mathrm{a}}=0.6038( \pm 0.2587)+07711( \pm 02606) \mathrm{DlP} \\
\left(\mathrm{l}:=\mathrm{X} 779 . \mathrm{l}^{\prime}=(0006, \mathrm{n}=30)\right.\end{array}$ \\
\hline
\end{tabular}

A regression of chlorophyll a on DIP combining all lakes and all four seasons accounted for about $25 \%$ (r2) of the chlorophyll a:

Chl-a $=0.44364( \pm 0.1190)+0.8646( \pm 0.1150)$ DIP $(F=56.543$, $\mathrm{P}<0.001, \mathrm{n}=175)$.

The Braças Chl-a/DIP relationship prescntcd a higher slope $(\mathrm{F}=19.812, \mathrm{P}<0.001, \mathrm{n}=32): \mathrm{Chl}-\mathrm{a}=-0.0577( \pm 0.2903)$ $+1.3198( \pm 0.2856)$ DIP.

In Vela and Mira lakes correlation values wcre not significant, respectively:

Chl-a $=1.4687( \pm 0.1593)-0.2587( \pm 0.1625)$ DIP $(\mathrm{F}=2.535$, $\mathrm{P}=0.12, \mathrm{n}=72$ );

Chl-a $=1.7119( \pm 0.1451)-0.2275( \pm 0.1325)$ DIP $(\mathrm{F}=2.946$, $\mathrm{P}=0.09, \mathrm{n}=71$ ).

Table 3. The $\mathrm{q}$ statistic test $(\alpha=0.05$ and $\mathrm{v}=1)$ ) for observed interactions between four regression models in order to conclude which slopes arc equal which others (Ho: $\left.\beta_{\mathrm{a}}=\beta_{\mathrm{b}}\right)$.

Tabla 3. Test estadístico $q(\alpha=0,05$ y $v=1)$ de las interacciones observadas entre los cuatro modelos de regresión para determinar la igualdad de las pendientes $(\mathrm{Ho}: a=b)$

$\begin{array}{lll}\text { winter vs spring } & \mathrm{q}=-2.4819: \mathrm{p}=104 & \text { accepted } \\ \text { winter vs summer } & \mathrm{q}=-10421, \mathrm{p}=93 & \text { accepted } \\ \text { uinter vs autumn } & \mathrm{q}=3.8674: \mathrm{p}=84 & \text { not accepted } \\ \text { spring vs summer } & \mathrm{q}=1.7804: \mathrm{p}=89 & \text { accepted } \\ \text { spring vs autumn } & \mathrm{q}=6.3634: \mathrm{p}=80 & \text { not accepted } \\ \text { summer vs autumn } & \mathrm{q}=5.8934: \mathrm{p}=69 & \text { not accepted }\end{array}$

All models fitted to each season (winter, spring, summer and autumn) (Tab.2) wcre significant; in summer $71.5 \%$ of the 
variability in Chl-a was explained by DIP. In winter and summer, slopes were higher than 1 , which means that a significant portion of DIP was available for Chl-a. For spring and autumn models, the slope is near 0.7 , which suggests a great difference in the availability in DIP.

After having calculated a regression equation for each set of data from all lakes by season, we have compared all slopes (B) in order to test whether they were equal. We have rejected the null hypothesis $(\mathrm{F}=12.9$, d.f. $=167, \mathrm{k}=4)$. Thus, a multiple comparison test was made in order to calculate which slopes were equal to which others. We have concluded that winter $=$ spring=summerautumn $($ Tab. 3$)$. Thus, a new regression model. combining three seasons (winter, spring and summer). was made and accounted for about $31 \%$ (r2) of the chlorophyll a:

Chl-a=0.2711 $( \pm 0.1311)+1.0083( \pm 0.1256) \mathrm{DIP}(\mathrm{F}=64.426$, $\mathrm{P}<0.001, \mathrm{n}=145$ ).

\section{DISCUSSION}

The simplest and most generally valid criterion used to assess an acceptable trophic level and the conditions to phytoplankton or macrophytes standing crops is the knowledge of nutrient availability and concentrations and, on the other hand, the physical characteristics of lakcs, like water depth associated to temperature stratification. It appeared to be important on lake restoration management by reducing the nutrient loading (c.g. O'SULLIVAN, 1992; QUIROS, 1990, SEIP, 1994, SEIP \& GOLDSTEIN, 1994).

Vela and Mira lakcs appear to have similar Chl-a/DIP relationships and are very different from Braças lake. The low slopes associated to the first models, suggest that $\mathrm{P}$ inputs to those lakcs are rapidly bounded to particles. These lakcs, which receive substantial urban runoff or stormwater from agricultural areas, usually havc a high concentration of DIP, over $1 \mathrm{mg} / \mathrm{l}$ (Fig. 3). This tends to be adsorbed by suspended clays and, hy flocculation, rapidly settled (SOBALLE \& THRELKELD, 1988; REDFIELD, 1991). Several authors (e.g. TRIMREE \& PREPAS, 1987; BERGE 1990) found that DIP was a good predictor of total and relative amounts of bluegreen algae and that shallow lakcs can tolerate higher phosphorus concentrations than deep lakes. However, in Mira lake, an external loading from the bait used in sport fishing, may increase DIP temporarily and be responsible for cyanobacteria blooms (BARROS et al., 1993; VASCONCELOS, 1994). On the other hand, DIP is not the limiting nutrient and the DINIDIP ratio was lower than 15 . The low ratios are known to control the formation of algal blooms and are characteristic of cutrophic systems (BARICA, 1990). Also, during this period the DIN concentrations decreased, with oscillations, and showed an additive effect of the low ammonia concentrations, making inorganic nitrogen less available. This relative lack of available nitrogen could be compensated by nilrogen fixation (PETTERSSON, 1990). In winter, high concentrations of chlorophyll a, followed by the decrease of DIP and an increase in DINIDIP ratio, may in part reflect the re-suspension of benthic algae, during storm events, and the reduced nutrient competition from benthic producers (PHLIPS et al., 1993). On the other hand, JENSEN \& ANDERSEN (1990) havc observed a net retention of phosphorus by the sediment, during the winter in shallow temperate lakes, while SAS (1990) states that periodic $\mathrm{P}$ release from sediment is common and occurs during the growing season. In Mira lake we have observed a great increasc in dissolved oxygen that accelerates the rates of release of phosphorus and nitrogen from the organic matter (RAVERA, 1990).

In contrast, the Vela lake, without in- and outflow. showed the DINIDIP ratio higher than Mira lake, during the start of this study, and confirms the lower chlorophyll a level. In this situation, phosphorus would be the limiting nutrient (AHLGREN \& ABEGAZ, 1993). Probably, this high DINIDIP ratio may be due to the external $\mathrm{N}$ input from stormwater andlor to high nitrate regeneration at the sediment-water interface. This nitrification could be limited by oxygen supply and by ammonium (DUDEL et al., 1993). The phytoplankton standing crops were relatively constant along the year, showing a little trend to increase at the end of study (winter season). This fact may be associated to the large areas with extensive submerged plant/epiphyte communities. These communities used nutrients and exhibited the opposite seasonal pattern from phytoplankton with a limited standing crop during the winter. Both Mira and Vela lakes are large areas with macrophytes and this bcnthic production could restrict the nutrients available to phytoplankton (PHLIPS et al., 1993).

\section{ACKNOWLEDGEMENTS}

This research was supported by a grant for F. Gonçalves (BIC 861193, PFMRH - JNICT) and by the projects PEAM/C/CNT/38/91 and PBIC/C/AGR/2269/95 from Junta Nacional de Investigação Científica e Tecnolbgica. 


\section{REFERENCES}

AHLGREN, I. \& Z. ABEGAZ 1993. Interactions of light, nutrients and stratification regimes in controlling phytoplankton primary production in cutrophic lakes. Verh. Internat. Verein. Limnol., 25: 506-511.

BARICA, J. 1990. Long-term trends in Great Lakes nutrient concentrations: a summary. Verh. Internat. Verein. Limnol., 24: 369-370.

RARROS, P., S. SILVEIRA, R. RIBEIRO, F. GONCALVES, V. VASCONCELOS \& A.M.V.M. SOARES 1993 Estrutura populacional fitoplanctdnica nas lagoas das Braças, Vela e Mira (região centro-litoral). Resultados preliminares. Boletim Uca, I: 1-8.

BERGE, D. 1990. Fosres - a phosphorus loading model for shallow lakes. Verh. Internat. Verein. Limnol., 24: 218-223.

DUDEL. G.E., B. RECHENBERG. \& K. HILBIG 1993. The contribution of the water-sedimcnt-interface to the nitrogen transformation in shallow lakes. Verh. Internat. Verein. Limnol., 25: 639-645.

JENSEN, H. S. \& F. ANDERSEN 1990. Impact of nitrate and blue-green algae abundance on phosphorus cycling between sediment and water in two shallow, eutrophic lakes. Verlz. Internat. Verein. Limnol., 24: 224-230.

KOROLEFF, F. 1970. Direct determination of ammonia in natural waters as Indophenol blue. Information on techniques and methods for seawater analysis. Cons. Int. Explor. Mer Service Hydrographique. Interlaboratory Report, 3: 19-22.

O'SULLIVAN, P. E. 1992 The eutrophication of shallow coastal lakes in Southwest England - understanding and recommendations for restoration, based on palaeolimnology, historical records, and the modelling of changing phosphorus loads. Hydrobiologia, 2431244: 421-434.

PETTERSSON, K., V. ISTVÁNOVICS, \& D. PIERSON 1990. Effects of vertical mixing on phytoplankton phosphorus supply during summer in Lake Erken. Verh. Internat. Verein. Limnol., 24: 236-241.

PHLIPS, E.J., P. V. ZIMBA, M.S. HOPSON \& T.L. CRISMAN 1993. Dynamics of the plankton community in submerged plant dominated regions of Lakc Okeechobee, Florida, USA. Verlz. Internat. Verein. Limnol., 25: 423-426.
QUIRÓS. R. 1990. Factors related to variance of residuals in chlorophyll - total phosphorus regressions in lakes and reservoirs of Argentina. Hydrobiologia, 200/201: 343-355.

RAVERA, O. 1990. The effects of hypolimnetic oxygenation in the shallow and eutrophic Lake Comabbio (Northern Italy) studied by "enclosure". Verh. Internat. Verein. Limnol., 24: 188-194.

RODRIGUES, A., P. BARROS, M. REIS, R. RIBEIRO, F. GONCALVES \& A.M.V.M. SOARES 1993. Comparação da variação temporal das comunidades zooplanctónicas nas lagoas das Braças, Vela e Mira (região centro-litoral). Resultados preliminares. Boletim Uca, I: 164-172.

REDFIELD, G. W. 1991. Phosphorus. chlorophyll and the comparative limnology of three suburban lakes in Northern Virginia, U.S.A.. Verh. Internat. Verein. Limnol., 24: 1294 1299.

SAS, H. 1990. Lake restoration by reduction of nutrient loading: Expectations, experiences, extrapolations. Verh. Internat. Verein. Limnol., 24: 247-251.

SEIP, K.L. 1994. Phosphorus and nitrogen limitation of algal biornass across trophic gradients. Aquatic Sciences, 56(1): 16-28.

SEIP, K.L. \& H. GOLDSTEIN 1994. Different responses to changes in phosphorus, $\mathrm{P}$, among lakes. A study of slopes in chl-a=f(P) graphs. Hydrobiologia 286: 27-36.

SOBALLE, D. M. \& S.T. THRELKELD 1988. Algal-clay flocculation in turbid waters: variation due to algal and mineral differences. Verh. Internat. Verein. Limnol., 23: 750-754.

STRICKLAND, J. D. H. \& T.R. PARSONS 1972. A practical handbook of seawater analysis. Bull. Fish. Res. Bd Canada, 167: $311 \mathrm{pp}$

TRIMREE, A. M. \& E.E. PREPAS 1987. Evaluation of total phosphorus as a predict of the relative biomass of bluegreen algae with emphasis on Alberta lakes. Can. J. Fish. Aquatic Sci., 44: 1337-1342.

VASCONCELOS. V. 1994. Toxic cyanobactcria (blue-green algae) in Portuguese fresh waters. Arch. Hydrobiol., 130(4): 439-451.

ZAR, J. H. 1984. Biostatistical analysis. 1-718. - Prenticc-Hall. Inc., New Jersey. 